\title{
KINESIO TAPING® METODO TAIKYMAS SERGANTIEMS KELIO SĄNARIO ARTROZE Literatūros sisteminẻ apžvalga
}

\author{
Venta Donec, Lina Nausėdaitė, Artūras Daukantas, Aurelija Beigienė \\ Lietuvos sveikatos mokslu universiteto ligonines Kauno kliniku Reabilitacijos klinika
}

Raktažodžiai: kelio sąnario artrozė, patelofemoralinio skausmo sindromas, Kinesio Taping ${ }^{\circledR}$ metodas.

\begin{abstract}
Santrauka
Gonartrozé - viena dažniausių degeneracinių sąnarių ligų, nustatomų vyresnio amžiaus pacientams, kuri sukelia skausmą, blogina judejjimo funkciją, darbingumą, gyvenimo kokybę. Ivairiais gydymo būdais (konservatyviais ir operaciniais) galima pristabdyti ligos progresavimą, sumažinti skausmą, atkurti ar kompensuoti biosocialinių funkcijų sutrikimus, pagerinti gyvenimo pilnatvę, nutolinti negalią. Šios sisteminès apžvalgos tikslas yra apibendrinti randomizuotus klinikinius tyrimus, kuriuose buvo nagrinetas Kinesio Taping ${ }^{\circledR}$ metodo taikymas sergantiems kelio sąnario artroze, tikslu pagerinti judèjimo funkciją, mažinti skausmą.

I apžvalgą ịtraukti straipsniai (pagal atrankos protokolą) apie tyrimus, kuriuose vertintas Kinesio Taping ${ }^{\circledR}$ metodo efektyvumas sergantiems kelio sąnario artroze. Paieška atlikta 2014 m. lapkričio mènesį. Ieškoti straipsniai publikuoti iki $2014 \mathrm{~m}$. spalio ménesio imtinai su nuorodomis i visos apimties straipsnius. Paieškos metu buvo naudojamos kompiuterinès bibliografinès duomenų bazès „PubMed“, „ScienceDirect“, „CochraneLibrary”, „Google Scholar”. Iš viso rasta 370 nuorodų ị straipsnius. Paaiškejjus, kad rastas tik vienas tinkamas išsamus straipsnis, nuspręsta papildyti atrankos kriterijus, ị apžvalgą įtraukiant ir straipsnius apie biomedicininius randomizuotus tyrimus, nagrinejusius Kinesio Taping ${ }^{\circledR}$ metodo efektyvumą tiriamiesiems, kurie skundžiasi kelio sąnario skausmu, arba yra nustatytas patelofemoralinio skausmo sindromas. Antrame etape rasta 1385 nuorodos i straipsnius, kuriu tinkamumas analizuotas pagal sisteminès atrankos protokolą.
\end{abstract}

Mūsų įtraukimo kriterijus atitiko 4 straipsniai. Viename analizuotas Kinesio Taping ${ }^{\circledR}$ metodo efektyvumas sergantiems kelio sąnario artroze, kitu trijų straipsnių autoriai nagrinèjo šio metodo poveiki asmenims, kuriems pasireiškè patelofemoralinio skausmo sindromas. Apžvelgus straipsnius nustatyta, kad buvo naudotos skirtingos Kinesio Taping ${ }^{\circledR}$ metodikos, net ir esant tai pačiai patologijai. Vertinant autoriu pateikiamas išvadas apie metodo efektyvumą gerinant judejjimo funkciją tiriamiesiems, rezultatai taip pat prieštaringi: tyrime, kur tirti sergantieji gonartroze, įrodytas Kinesio Taping ${ }^{\circledR}$ metodo pranašumas mažinant skausmą bei didinant keturgalvio raumens jègą, palyginus su placebo teipavimu, kai tuo tarpu kitu studijų, nagrinejjusių metodo efektyvumą sergantiems patelofemoralinio skausmo sindromu, tyrejai nenustate Kinesio Taping ${ }^{\circledR}$ metodo pranašumo, palyginus su $m$. vastus medialis ir lateralis elektrostimuliacija, ar vien tik su kineziterapija, ar su placebo teipavimu. Nustatyta, kad kai kurie nagrinèti tyrimai turi nemažą riziką šališkumo dèl metodologinių trūkumų.

Iš apžvelgtų tyrimų duomenų negalime įvertinti Kinesio Taping ${ }^{\circledR}$ metodo efektyvumo sergantiems kelio sąnario artroze. Pageidautina atlikti daugiau kokybiškų tyrimų, kurie leistų spręsti apie Kinesio Taping ${ }^{\circledR}$ metodo naudą gydant sergančius gonartroze.

\section{Ivadas}

Gonartrozė yra lètinè progresuojanti degeneracinè kelio sąnario liga, pažeidžianti kelio sąnario kremzlę bei daugumą aplinkinių audinių. Ligai progresuojant stebimas subchondrinio kaulo remodeliavimasis, osteofitu formavimasis, vystosi raiščių laisvumas, atsiranda raumenų silpnumas, gali pasireikšti sinovitas. Pirmieji klinikiniai simptomai dažniausiai yra kelio sąnario skausmas, sustingimas, riboti judesiai. Progresuojant ligai intensyvejja skausmas, 


\section{4}

visiškai sutrinka kelio sąnario funkcija, atsiranda negalia (1). Gonartrozė yra viena dažniausių degeneracinių sąnarių ligų, nustatomų vyresnio amžiaus asmenims, kuri sukelia skausmą, blogina judejjimo funkciją, darbingumą, gyvenimo kokybę (1-3). Literatūros duomenimis, ryškūs radiologiniai pokyčiai būdingi kelio sąnario artrozei nustatomi 1\% 25-34 metų asmenims, o vyresniems nei 75 metai šie požymiai randami jau beveik $50 \%$ (1). Vyresniems nei 60 metų pacientams gonartrozè gali būti nustatoma $12 \%$ $-37 \%$ (2). Moterų sergamumas šia liga didesnis nei vyrų, ịvairių šaltinių duomenimis, santykis gali siekti nuo 1,5:1 iki 4:1 (1). Šiuo metu gonartrozè yra nepagydoma liga, tačiau ịvairiais gydymo būdais (konservatyviais ir operaciniais) galima sulètinti ligos progresavimą, sumažinti skausmą, atkurti ar kompensuoti ligos sąlygotų biosocialinių funkcijų sutrikimus, pagerinti gyvenimo pilnatvę, nutolinti negalią (3-7).

Kinesio Taping ${ }^{\circledR}$ metodas buvo sukurtas dr. Kenso Kase. Jo esmé - specialiai šiam metodui sukurtų lipnių juostų klijavimas ant odos specialia metodika, tikslu koreguoti judèseną, mažinti skausmą, gerinti propriocepciją, kraujotaką, limfotaką (8). Per mažiau nei 30 metų nuo išradimo, Kinesio Taping ${ }^{\circledR}$ metodas labai išpopuliarejo visame pasaulyje ir buvo pradetas plačiai naudoti sporte, klinikinëje praktikoje, traumų gydymui ir profilaktikai. Metodo populiarumą sąlygojo ir tai, jog jis gali būti saugiai derinamas su kitais gydymo būdais. Lipnios juostelès yra hipoalerginès, todèl taisyklingai naudojant, šalutinis poveikis (galimas odos sudirginimas) gyvybei negrésmingas ir retas (9-13). Vis dèlto, nepaisant plataus taikymo, klinikinių studijų, tyrinejjusių šio metodo efektyvumą gydant ịvairias ligas, nèra daug. Daugumos atliktų tyrimų mokslinė vertė maža, rezultatai prieštaringi (13-15). Klinikinèse gairèse, skirtose kelio sąnario artrozès neoperacinio gydymo rekomendacijoms apibrèžti, kelio girnelès teipavimas rekomenduojamas kaip konservatyvus gydymo būdas, galintis pagerinti judejimo funkciją, sumažinti skausmą sergantiems kelio sąnario artroze $(4,5)$. Vis dèlto klinikiniu gairiu cituojamuose tyrimuose, nurodančiuose galimą teipavimo naudą sergantiems kelio sąnario artroze, naudotos ne Kinesio Taping ${ }^{\circledR}$ teipavimo metodikos $(16,17)$. Kinesio Taping ${ }^{\circledR}$ metodo pranašumas prieš ankstesnius teipavimo metodus slypi tame, jog naudojamos specialiai šiam metodui sukurtos lipnios juostelès, kurios yra hipoalerginès, atsparios vandeniui, gali būti saugiai nešiojamos ant kūno keletą parų (paprastai 3-5 paras) be žalos odai ir poreikio perklijuoti; dèl elastinių juosteliu savybių, taisyklingai atlikus teipavimą, išradejo teigimu, galime gauti pageidaujamus terapinius poveikius neapribojant judesių, todèl šis metodas ypač palankus, kuomet vienas gydymo tikslų yra išsaugoti judesius ar didinti pagei- daujamo judesio amplitudę. Kenzo Kase ir bendraautoriai klinikinèse šio metodo taikymo rekomendacijose nurodo, kad Kinesio Taping ${ }^{\circledR}$ metodas gali būti naudojamas kaip pagalbinis konservatyvus gydymo būdas, norint sumažinti lètinį sąnario tinimą bei skausmą, gerinti judèseną ir propriocepciją sergantiems kelio sąnario artroze (8).

Tyrimo uždaviniai: nustatyti juostelių klijavimo metodus, taikytus sergantiems kelio sąnario artroze, palyginti gydymo rezultatus, apžvelgti nepageidaujamus Kinesio Taping ${ }^{\mathbb{R}}$ metodo taikymo poveikius, ivvertinti tyrimų kokybę.

Šios literatūros sisteminès apžvalgos tikslas - apibendrinti biomedicininius randomizuotus tyrimus, kuriuose buvo nagrinetas Kinesio Taping ${ }^{\circledR}$ metodo efektyvumas sergantiems kelio sąnario artroze.

\section{Tyrimo medžiaga ir metodai}

Prieš pradedant sisteminę apžvalgą, buvo sudarytas sisteminès literatūros apžvalgos protokolas, nustatantis įtraukimo ir atmetimo kriterijus.

İtraukimo i̇ sisteminę apžvalgą kriterijai: išsamūs straipsniai apie randomizuotus klinikinius tyrimus, kuriuose taikytas Kinesio Taping ${ }^{\circledR}$ metodas atskirai ar drauge su kitais gydymo būdais sergantiems kelio sąnario artroze.

Atmetimo kriterijai: į apžvalgą neįtrauktos santrumpos, konferencijų tezès, stendiniai pranešimai, atvejų aprašymai, nerandomizuoti tyrimai, ekspertų nuomonės apie Kinesio Taping ${ }^{\circledR}$ metodo taikymą sergantiems kelio sąnario artroze, taip pat publikacijos, parašytos ne anglų kalba, bei sisteminės apžvalgos ar straipsniai apie tyrimus, kur Kinesio Taping ${ }^{\circledR}$ metodas taikytas esant kitoms patologijoms ar sveikiems asmenims. Taip pat neitrauktos publikacijos, kuriose taikytas kitoks teipavimo metodas, ar nebuvo galima nustatyti teipavimo metodo rūšies iš straipsniuose pateikiamos informacijos sergantiems kelio sąnario artroze.

Paieškos strategija. Paieška atlikta $2014 \mathrm{~m}$. lapkričio mènesį. Ieškoti straipsniai publikuoti iki $2014 \mathrm{~m}$. spalio mènesio imtinai su nuorodomis ị išsamius straipsnius. Paieškos metu buvo naudojamos kompiuterinès bibliografinès medicininès duomenu bazès „PubMed“, „ScienceDirect“, „CochraneLibrary”, „Google Scholar”. Ieškant straipsnių, ne tik jų santraukų, kreiptasi į kai kurių straipsnių autorius. Paieškos raktažodžiai: „knee osteoarthritis [MeSH Terms]”, „kinesio taping“, „kinesio tape“, „kinesiotaping”, „elastic taping”, „kinesiology taping”. Pirmame etape iš straipsnio pavadinimo buvo sprendžiama, ar straipsnis tinka nustatytiems atrankos kriterijams, antrame etape - iš straipsnio santraukos, trečiame - iš viso straipsnio.

Kadangi atlikus paiešką pagal suformuluotus atrankos kriterijus rasta vos trijų randomizuotų tyrimų santrumpos, iš kurių viena japonų kalba, o susisiekus su autoriais iš jų 
1 lentelè. Pagrindiniai tyrimų, nagrinèjusių Kinesio Taping ${ }^{\circledR}$ metodo efektyvumą sergantiems gonartroze ar patelofemoralinio skausmo sindromu, duomenys

\begin{tabular}{|c|c|c|c|c|}
\hline Tyrimas & $\begin{array}{l}\text { Anandkumar ir kiti } \\
2014 \text { India }\end{array}$ & $\begin{array}{l}\text { Ayetar ir kiti } \\
2011 \text { Turkija }\end{array}$ & $\begin{array}{l}\text { Akbas ir kiti } \\
2011 \text { Turkija }\end{array}$ & $\begin{array}{l}\text { Kuru T. ir kiti } \\
2012 \text { Turkija }\end{array}$ \\
\hline Tyrimo tipas & $\begin{array}{l}\text { Randomizuotas dvigubai } \\
\text { aklas klinikinis tyrimas, } \\
\text { monocentrinis }\end{array}$ & $\begin{array}{l}\text { Randomizuotas dvigubai } \\
\text { aklas klinikinis tyrimas, } \\
\text { monocentrinis }\end{array}$ & $\begin{array}{l}\text { Randomizuotas klinikinis } \\
\text { tyrimas, monocentrinis }\end{array}$ & $\begin{array}{l}\text { Randomizuotas klinikinis } \\
\text { tyrimas, monocentrinis }\end{array}$ \\
\hline Tiriamieji & $\begin{array}{l}\text { n } 40 \\
\text { Sergatys I-II laipsnio kelio } \\
\text { sąnario artroze }\end{array}$ & $\begin{array}{l}\text { n } 22 \\
\text { Moterys, kurioms } \\
\text { nustatytas } \\
\text { patelofemoralinio } \\
\text { skausmo sindromas }\end{array}$ & $\begin{array}{l}\text { n } 31 \\
\text { Moterys, kurioms } \\
\text { nustatytas } \\
\text { patelofemoralinio } \\
\text { skausmo sindromas }\end{array}$ & $\begin{array}{l}\text { n } 30 \\
\text { Tiriamieji, kuriems } \\
\text { nustatytas } \\
\text { patelofemoralinio } \\
\text { skausmo sindromas }\end{array}$ \\
\hline $\begin{array}{l}\text { Tyrimo } \\
\text { tikslas }\end{array}$ & $\begin{array}{l}\text { Kinesio Taping poveikis } \\
\text { maksimaliam izokinetiniam } \\
\text { keturgalvio raumens } \\
\text { sukimosi momentui }\end{array}$ & $\begin{array}{l}\text { Kinesio Taping poveikis } \\
\text { skausmui, jègai, sąnario } \\
\text { padėties pojūčiui ir } \\
\text { pusiausvyrai }\end{array}$ & $\begin{array}{l}\text { Kinesio Taping poveikis } \\
\text { gydant patelofemoralinio } \\
\text { skausmo sindromą }\end{array}$ & $\begin{array}{l}\text { Palyginti Kinesio Taping } \\
\text { metodo efektyvumą su } \\
\text { elektrostimuliacijos } \\
\text { poveikiu skausmui ir } \\
\text { kelio sąnario funkcijai, } \\
\text { sergantiems } \\
\text { patelofemoralinio } \\
\text { skausmo sindromu }\end{array}$ \\
\hline $\begin{array}{l}\text { Grupės; } \\
\text { amžiaus } \\
\text { vidurkis }\end{array}$ & $\begin{array}{l}\text { Kinesio Taping grupè } \\
\text { n } 20(55,7 \pm 5,8), \\
\text { Placebo grupe } \\
\text { n } 20(55,9 \pm 5,0)\end{array}$ & $\begin{array}{l}\text { Kinesio Taping grupé } \\
\text { n } 12(22,14 \pm 1,6) \\
\text { Placebo grupe } \\
\text { n } 10(26,2 \pm 3,52)\end{array}$ & $\begin{array}{l}\text { Kinesio Taping grupé } \\
\text { n } 15(41.00 \pm 11.26) \\
\text { Kontrolinė grupe } \\
\text { n } 16(44,88 \pm 7,75)\end{array}$ & $\begin{array}{l}\text { Kinesio Taping grupé } \\
\text { n } 15(32,93 \pm 12,17), \\
\text { Elektrostimuliacijos grupé } \\
\text { n } 15(40,93 \pm 10,57)\end{array}$ \\
\hline Intervencija & $\begin{array}{l}\text { Kinesio Taping grupė: } \\
\text { taikytos trys „I“ formos } \\
\text { juostelès: I - virš m. rectus } \\
\text { femoris, II - virš m. vastus } \\
\text { lateralis, III - virš m. } \\
\text { vastus medialis (klijavimo } \\
\text { kryptis: nuo raumens } \\
\text { pradžios link pabaigos; } \\
\text { taikytas juostelės tempimas } \\
\text { 50-75 \%, klijų } \\
\text { aktyvavimas); } \\
\text { Placebo grupé: } \\
\text { taikytos trys „I“ formos } \\
\text { juostelės, vieta identiška } \\
\text { kaip ir Kinesio Taping } \\
\text { grupeje, tik klijuota } \\
\text { nenaudojant juostelų } \\
\text { tempimo, bei klijų } \\
\text { aktyvavimo. } \\
\text { Abejose grupėse klijuotos } \\
\text { Kinesio Taping metodo } \\
\text { juostelės. }\end{array}$ & $\begin{array}{l}\text { Kinesio Taping grupė: } \\
\text { teipuota aktyvinančia } \\
\text { metodika } m \text {. rectus } \\
\text { femoris (naudotas } \\
\text { tempimas ,paper off“), } 3 \\
\text { juostelès apgaubiant } \\
\text { girnelę mechaninès } \\
\text { korekcijos metodika } \\
\text { (taikytas juostelès } \\
\text { tempimas 50-75 \%). } \\
\text { Placebo grupé: } \\
\text { tokia pati klijavimo } \\
\text { metodika, tik nenaudotas } \\
\text { tempimas ir klijuota ne } \\
\text { Kinesio Taping metodo } \\
\text { juostelè, o panaši ị ją. }\end{array}$ & $\begin{array}{l}\text { Kinesio Taping grupe: } \\
\text { taikyta } 6 \text { sav. namų } \\
\text { kineziterapijos programa } \\
+6 \text { sav. } \\
\text { kinezioteipavimas (penkių } \\
\text { dienų intervalais). } \\
\text { Juostelès klijuotos: } m \text {. } \\
\text { vastus medialis ir } m \text {. } \\
\text { rectus femoris } \\
\text { "aktyvinančia“ metodika, } \\
\text { m. vastus lateralis, } \\
\text { šlaunies lenkejjai, } \\
\text { iliotibialinis traktas } \\
\text { „slopinančia“ metodika. } \\
\text { Kontrolineje grupė: } \\
\text { taikyta tik identiška } 6 \text { sav. } \\
\text { namų kineziterapijos } \\
\text { programa. }\end{array}$ & 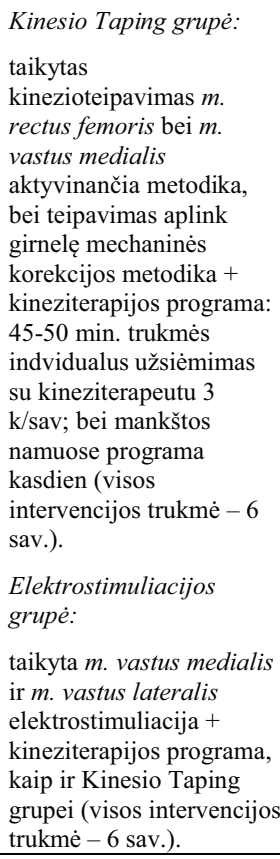 \\
\hline $\begin{array}{l}\text { Tirti } \\
\text { parametrai }\end{array}$ & $\begin{array}{l}\text { Keturgalvio raumens } \\
\text { maksimalus sukimosi } \\
\text { momentas (koncentrinis ir } \\
\text { ekscentrinis } 90 \% \text { s, } 120 \% \text { s } \\
\text { kampiniu greičiu); lipimo } \\
\text { laiptais greitis ir skausmo } \\
\text { intensyvumas pagal VAS, } \\
\text { lipant laiptais. }\end{array}$ & $\begin{array}{l}\text { Keturgalvio raumens } \\
\text { maksimalus sukimosi } \\
\text { momentas (koncentrinis ir } \\
\text { ekscentrinis } 60 \% \text { s, } 180 \% \text { s } \\
\text { kampiniu greičiu); kelio } \\
\text { sąnario padeties jutimas; } \\
\text { skausmas; statinè ir } \\
\text { dinamine pusiausvyra. }\end{array}$ & $\begin{array}{l}\text { Skausmo intensyvumas } \\
\text { ramybejje, po ilgesnio } \\
\text { sėdejjimo sulenkus kelius, } \\
\text { einant, klūpint, tupiant, } \\
\text { kopiant i kalną ir } \\
\text { leidžiantis žemyn, kylant } \\
\text { ir leidžiantis laiptais; } \\
\text { kaliperis girnelès padėties } \\
\text { ivvertinimui; Ober testas; } \\
\text { blauzdos lenkèjų }\end{array}$ & $\begin{array}{l}\text { Skausmo intensyvumas } \\
\text { pagal VAS; keturgalvio } \\
\text { raumens jëga (manualinis } \\
\text { testavimas); Kujala skalė; } \\
\text { Testai: žingsniavimo, trijų } \\
\text { pašokimų, kelio sąnario } \\
\text { sulenkimo; SF-36 } \\
\text { klausimynas. }\end{array}$ \\
\hline
\end{tabular}




\begin{tabular}{|c|c|c|c|c|}
\hline Rezultatai & $\begin{array}{l}\text { Kinesio Taping grupeje: } \\
\text { padidejo keturgalvio } \\
\text { raumens sukimosi } \\
\text { momentas (koncentrinis ir } \\
\text { ekscentrinis } 90 \% \text { s, } 120 \% \text { s } \\
\text { kampiniu greičiu); } \\
\text { padidejo lipimo laiptais } \\
\text { greitis; sumažejo skausmo } \\
\text { intensyvumas lipant } \\
\text { laiptais. } \\
\text { Placebo grupeje: } \\
\text { po intervencijos } \\
\text { keturgalvio raumens jèga } \\
\text { reikšmingai nekito, stebètas } \\
\text { intensyvesnis skausmas ir } \\
\text { lètesnis lipimas laiptais. } \\
\text { Pagal visus kriterijus } \\
\text { nustatyti statistiškai } \\
\text { reikšmingi skirtumai tarp } \\
\text { Kinesio Taping grupès ir } \\
\text { placebo (p < 0,05). }\end{array}$ & 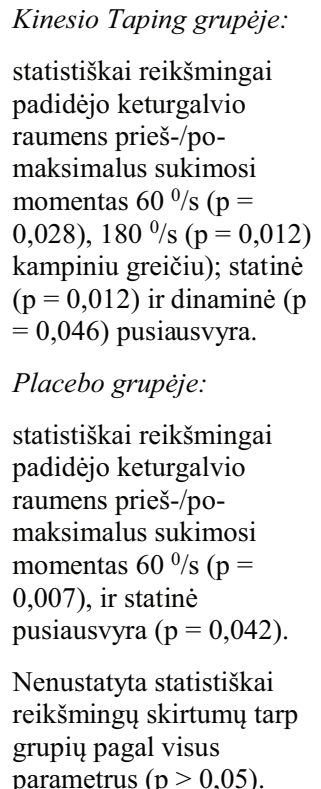 & $\begin{array}{l}\text { Abejose grupėse } \\
\text { nenustatyta girnelès } \\
\text { padèties pokyčio }(\mathrm{p}> \\
0,05), \text { o visi kiti rodikliai } \\
\text { pagerèjo }(\mathrm{p}<0,05) . \\
\text { Nenustatyta statistiškai } \\
\text { reikšmingų skirtumų tarp } \\
\text { grupių pagal tirtus } \\
\text { parametrus }(\mathrm{p}>0,05) .\end{array}$ & $\begin{array}{l}\text { Visos charakteristikos } \\
\text { statistiškai reikšmingai } \\
\text { pagerejo abejose grupèse } \\
(\mathrm{p}<0,05) \text {, tačiau } \\
\text { skirtumų tarp grupių } \\
\text { nenustatyta }(\mathrm{p}>0,05) .\end{array}$ \\
\hline
\end{tabular}

2 lentelè. Galimo šališkumo tyrimuose vertinimas

\begin{tabular}{|c|c|c|c|c|c|c|c|}
\hline & 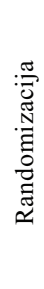 & 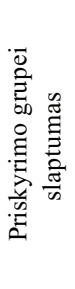 & 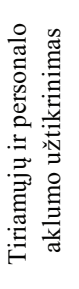 & 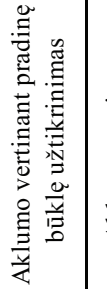 & 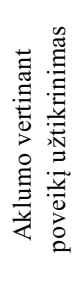 & 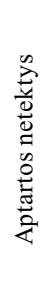 & 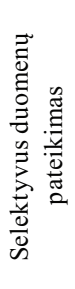 \\
\hline $\begin{array}{l}\text { Anandkumar } \\
\text { ir kiti, } 2014\end{array}$ & & & & & & & \\
\hline $\begin{array}{l}\text { Ay etar ir kiti, } \\
2011\end{array}$ & ? & 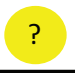 & & & & & \\
\hline $\begin{array}{l}\text { Akbas ir kiti, } \\
2011\end{array}$ & & & & & & ? & \\
\hline $\begin{array}{l}\text { Kuru ir kiti, } \\
2012\end{array}$ & & & & ? & ? & & \\
\hline & & & \multicolumn{2}{|c|}{ maža rizika } & & & \\
\hline & & & \multicolumn{2}{|c|}{ didelè rizika } & & & \\
\hline & & ? & \multicolumn{2}{|c|}{ nežinoma rizika } & & & \\
\hline
\end{tabular}

gautas tik vienas išsamus straipsnis, todèl buvo pakeista paieškos strategija: buvo nuspręsta papildyti ịtraukimo ị sisteminę apžvalgą kriterijus, ị ją ịtraukiant ir išsamius straipsnius apie randomizuotus klinikinius tyrimus, kuriuose nagrinètas Kinesio Taping ${ }^{\circledR}$ metodo efektyvumas patelofemoralinio skausmo sindromu sergantiems tiriamiesiems ar besiskundžiantiems kelio sąnario skausmu. Pastarieji požymiai nèra specifiniai, tačiau labai dažnai nustatomi sergantiems kelio sąnario osteoartritu $(18,19)$, todèl nuspręsta, jog tokių studijų pateikiami rezultatai gali suteikti aktualių žinių apie galimą Kinesio Taping ${ }^{\circledR}$ metodo poveikị sergantiems kelio sąnario artroze. Taigi antrajame etape paieška papildyta raktiniais žodžiais ,,patellofemoral pain syndrome [MeSH Terms]”, „knee pain”. Visas straipsnių atrankos procesas pavaizduotas 1 schemoje.

Iš atrinktų išsamių straipsnių surinkti duomenys apie tyrimo tipą, atliktą atranką, randomizaciją, tiriamuosius, jų skaičiu, juostelių klijavimo metodiką, intervencijos trukmę, stebejjimo laiką, vertintus tiriamųjų būklès pokyčius, gydymo rezultatus, nepageidaujamus poveikius. Galimas šališkumas (sisteminès klaidos) tyrimuose vertintas remiantis Kochrano bendrijos rekomenduojamu įrankiu (20).

\section{Rezultatai}

Atrinkti 4 išsamūs straipsniai, atitinkantys ịtraukimo kriterijus, viename iš jų buvo vertinamas Kinesio Taping ${ }^{\circledR}$ metodo efektyvumas sergantiems kelio sąnario artroze, kitų trijų straipsnių autoriai analizavo šio metodo poveikị asmenims, kuriems pasireiškè patelofemoralinio skausmo sindromas. Susisteminti tyrimų duomenys pateikiami 1 lentelèje.

Nei viename iš nagrinètų tyrimų autoriai nenurode Kinesio Taping ${ }^{\circledR}$ metodo nepageidaujamų poveikių, pažymètina, jog analizuotuose tyrimuose netekčių Kinesio Taping ${ }^{\circledR}$ metodo grupèse taip pat nebuvo. Atlikus straipsnių analizę nustatyta, kad buvo naudotos vis kitokios Kinesio teipavimo metodikos. Bendra tai, kad visi tyrèjai siekė paveikti 
1 schema. Sisteminès apžvalgos straipsnių atranka

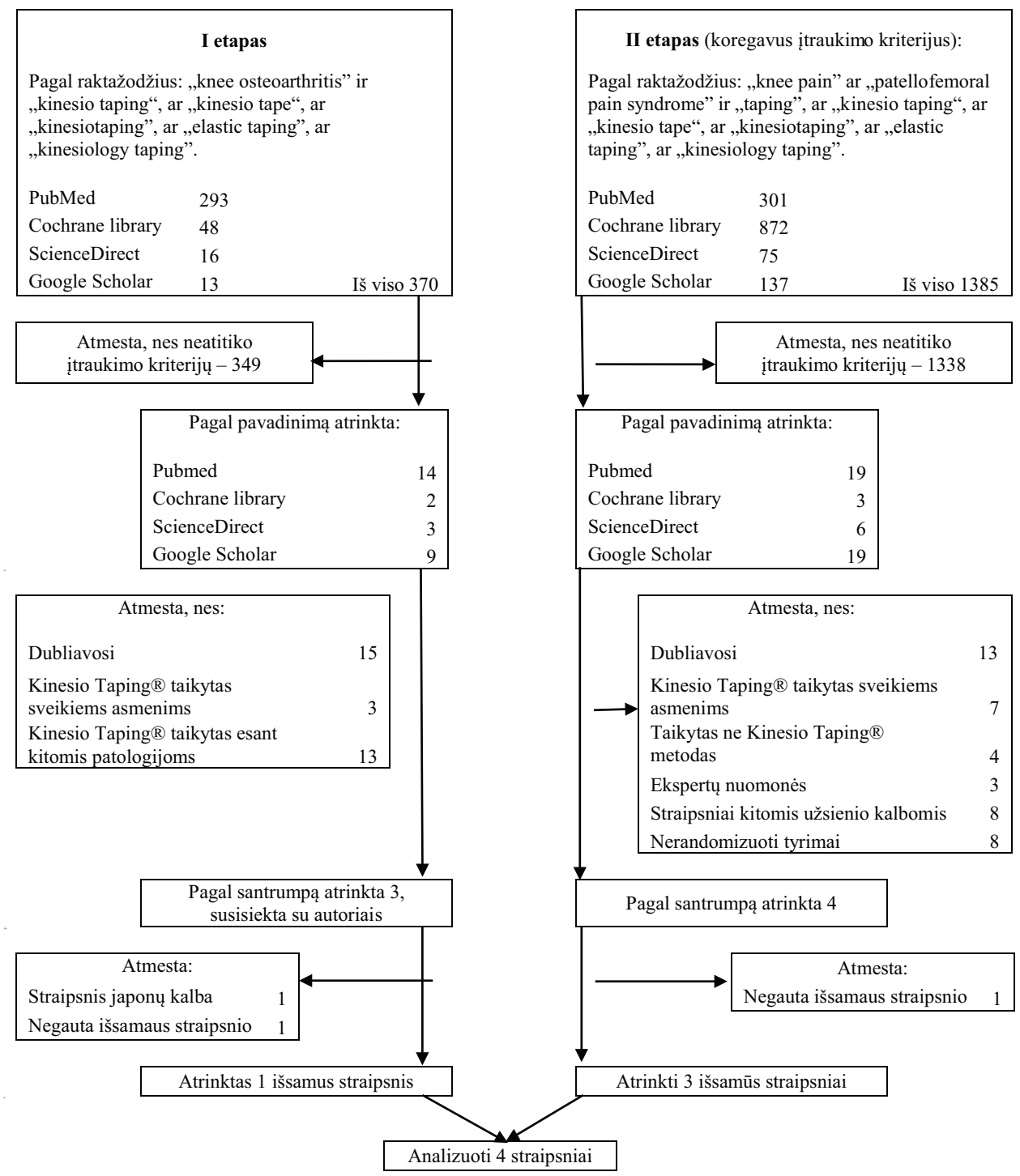

šlaunies raumenis, daugiausia keturgalvio raumens funkciją, tačiau klijuodami juosteles pasirinko skirtingą jų ịtempimo intensyvumą, klijavimo būdą, kai kurie taip pat naudojo girnelès mechaninès korekcijos teipavimo metodikas, todèl gautų rezultatų palyginimas sudètingas dèl ženklių metodologinių skirtumų. Nustatyta, jog tyrimuose, nagrinejusiuose patelofemoralinio sindromo atvejus, dalyvavo daugiausia jauno amžiaus tiriamieji (amžiaus vidurkis 2245 metai). Vertinant autoriu pateikiamas išvadas apie Kinesio Taping ${ }^{\circledR}$ metodo efektyvumą gerinant judèjimo funkciją tiriamiesiems, rezultatai prieštaringi: Anandkumar ir kt. atliktame tyrime nustatytas Kinesio Taping ${ }^{\circledR}$ metodo prana- šumas mažinant skausmą bei didinant keturgalvio raumens jëgą, palyginus su placebo teipavimu sergantiems gonartroze, kai tuo tarpu kitų studijų, vertinusių metodo efektyvumą sergantiems patelofemoraliniu sindromu, tyrejjai nenustatė Kinesio Taping ${ }^{\circledR}$ metodo pranašumo, palyginus su $m$. vastus medialis ir lateralis elektrostimuliacija (Kuru T. ir kiti 2012), ar vien tik su kineziterapija (Akbas ir kiti 2011), ar su placebo teipavimu (Ayetar ir kiti 2011).

Ivvertinus tyrimų kokybę bei šališkumo riziką pagal Kochrano bendrijos rekomenduojamą įrankị (20) nustatyta, jog mažiausiu galimu šališkumu pagal daugumą kriterijų pasižymi Anandkumar ir kolegų atliktas tyrimas (21), kitų 
autorių tyrimai turi nemažai metodologinių trūkumų. Tyrimų rezultatų ir išvadų galimo šališkumo rizikos vertinimas pateikiamas 2 lentelèje.

\section{Diskusija}

Kinesio Taping ${ }^{\circledR}$ metodo išradejo teigimu, šis metodas gali būti naudojamas kaip pagalbinis konservatyvaus gydymo būdas tikslu mažinti lètinị sąnario tinimą bei skausmą, gerinti judèseną ir propriocepciją sergantiems kelio sąnario artroze (8). Šios sisteminès apžvalgos tikslas buvo apibendrinti tyrimus, kuriuose vertintas Kinesio Taping ${ }^{\circledR}$ metodo efektyvumas sergantiems kelio sąnario artroze bei ịvertinti šio gydymo rezultatus, apžvelgti nepageidaujamus Kinesio Taping ${ }^{\circledR}$ metodo poveikius. Deja, atlikus sisteminę apžvalgą nustatyta, jog tèra keletas publikuotų straipsnių, vertinusių Kinesio Taping ${ }^{\circledR}$ metodo efektyvumą sergantiems kelio sąnaro artroze, iš jų vienas japonų kalba. Susisiekus su autoriais, gautas tik vienas išsamus straipsnis, kuriame Kinesio Taping ${ }^{\circledR}$ metodas naudotas sergantiems kelio sąnario artroze (rezultatas vertintas vienkartinai, $30 \mathrm{~min}$. po juostelių užklijavimo). Šio tyrimo autoriai nustatè, jog Kinesio Taping ${ }^{\circledR}$ metodo pritaikymas reikšmingai padidino šlaunies keturgalvio raumens sukimosi momentą, lipimo laiptais greitị, sumažino skausmo intensyvumą lipant laiptais sergantiems kelio sąnario artroze. Tačiau įvertinus tai, kad tiriamieji buvo sergantys I-II laipsnio gonartroze (pradinès stadijos) ir tirtas tik momentinis efektas (30 min. po teipavimo), manome, kad negalima rezultatu apibendrinti visiems gonartroze sergantiems pacientams. Lieka neaišku, kokio Kinesio Taping ${ }^{\circledR}$ metodo efekto tokiems pacientams būtų galima tikètis taikant teipavimą ilgiau, bei pacientams, kurių gonartozė yra labiau pažengusi.

Apžvelgus studijas, nagrinejjusias Kinesio Taping ${ }^{\circledR}$ metodo poveikị tiriamiesiems, kuriems buvo nustatytas patelofemoralinio skausmo sindromas (nustatomas ir gonartroze sergantiems), autorių pateikiami rezultatai neįrodo šio teipavimo metodo pranašumo gerinant judejjimo funkciją, mažinant skausmą, palyginus su placebo teipavimu, kineziterapija, elektrostimuliacija, nei artimajame laikotarpyje (30-45 min. po užteipavimo), nei po šešiu savaičių gydymo kurso. Vis dèlto atkreiptinas demesys, jog tyrimų, nagrinèjusių Kinesio Taping ${ }^{\mathbb{B}}$ metodo efektyvumą sergantiems patelofemoraliniu sindromu, imtys mažos. Todèl kyla abejone, ar jie apskritai buvo pakankamos imties, kad aptiktų galimus skirtumus. Ivertinus šių studijų kokybę pagal Kochrano bendrijos rekomenduojamus įrankius, nustatyta didelè šališkumo rizika, dẻl to negalima daryti galutinių išvadų apie metodo poveikị kelio sąnario skausmui, propriocepcijai, judejjimo funkcijai sergantiems patelofemoralinio skausmo sindromu. Svarbu ir tai, kad visose nagrinètose studijose pasirinktas skirtingas juosteliu klijavimo būdas (net ir esant tai pačiai patologijai). Pasak metodo išradejjo, naudojant skirtingą juostelių įtempimą, klijavimo krypti juostelių sukeliamas poveikis audiniams skiriasi (8), todèl studijų rezultatų palyginimas galimas tik iš dalies. Negalime atmesti, kad viena priežasčių, kodèl autoriai gauna skirtingus rezultatus apie Kinesio Taping ${ }^{\circledR}$ metodo efektyvumą, galèjo būti juosteliu klijavimo metodika. Nustatyta, kad dauguma Kinesio Taping ${ }^{\circledR}$ metodo poveiki patelofemoralinio sindromo atveju tyrinejjusių autorių tyrè jauno amžiaus asmenis, kas nebūdinga sergantiems gonartroze, todèl duomenų apie metodo efektyvumą sergantiems artroze trūksta.

Vertinant galimus Kinesio Taping ${ }^{\circledR}$ metodo nepageidaujamus poveikius platesnei populiacijai, duomenų apibendrinti negalime dẻl labai mažų tyrimo imčių. Vis dèlto tai, kad tyrimų autoriai neaprašè nepageidaujamų poveikių naudojant Kinesio Taping ${ }^{\circledR}$ metodą ir nebuvo netekčių Kinesio Taping ${ }^{\circledR}$ metodo grupèse, neprieštarautų šiuo metu literatūroje vyraujančiai nuostatai, kad Kinesio Taping ${ }^{\circledR}$ metodas yra gerai toleruojamas įvairaus amžiaus žmonių $(8,13,22)$.

\section{Išvados}

1. Atlikus sisteminę literatūros apžvalgą nustatyta, kad yra rašoma daug straipsnių Kinesio Taping ${ }^{\circledR}$ metodo efektyvumo vertinimo tema, tačiau šia tema publikuotu randomizuotų klinikinių tyrimų sergantiems kelio sąnario artroze yra nedaug.

2. İvertinus literatūros duomenis, šiuo metu negalima daryti galutinių išvadų apie Kinesio Taping ${ }^{\circledR}$ metodo efektyvumą sergantiems kelio sąnario atroze. Pageidautina atlikti daugiau kokybiškų tyrimų.

\section{Literatūra}

1. Litwic A, Edwards MH, Dennison EM, Cooper C. Epidemiology and burden of osteoarthritis. Br Med Bull [Internet]. 2013 Jan [cited 2014 Mar 15];105:185-99. Available from: http:// www.pubmedcentral.nih.gov/articlerender.fcgi?artid $=369043$ $8 \&$ tool $=$ pmcentrez\&rendertype $=$ abstract

2. Riddle DL, Kong X, Fitzgerald GK. Psychological health impact on 2-year changes in pain and function in persons with knee pain: data from the Osteoarthritis Initiative. Osteoarthritis Cartilage [Internet]. 2011 Sep [cited 2014 Mar 15]; 19(9):1095-101. Available from: http://www.pubmedcentral. nih.gov/articlerender.fcgi?artid=3159740\&tool=pmcentrez\&r endertype $=$ abstract

3. Juocevičius A., Michailovienè I., Burzdžienė R., Glamba V., Danys A. Pacientų, reabilituotų po klubo ir kelio sąnario endoprotezavimo operacijų trijose reabilitacijos paslaugas teikiančiose įstaigose, charakteristika [Internet]. Gerontologija. 2010 [cited 2014 Mar 9]. p. 11(2):77-83. Available from: 
http://www.gerontologija.lt/files/edit_files//File/pdf/2010/ nr_2/2010_77_83.pdf

4. Peter W, Jansen M, Hurkmans E, Bloo H, Dekker-Bakker L, Dilling R. et al. Physiotherapy in hip and knee osteoarthritis: development of a practice guide line concerning initial assessment, treatment and evaluation. Acta Reumatol Port 2011;36(3):268-81.

5. Hochberg MC, Altman RD, April KT, Benkhalti M, Guyatt G, McGowan J. et al. American College of Rheumatology 2012 recommendations for the use of nonpharmacologic and pharmacologic therapies in osteoarthritis of the hand, hip, and knee. Arthritis Care Res (Hoboken) [Internet]. 2012 Apr 27 [cited 2014 Feb 23]; 64(4):465-74. Available from: http://doi. wiley.com/10.1002/acr.21596

6. Hinman RS, Wrigley TV, Metcalf BR, Hunter DJ, Campbell P, Paterson K. et al. Unloading shoes for osteoarthritis of the knee: protocol for the SHARK randomised controlled trial. BMC Musculoskelet Disord [Internet]. 2014 Feb 21 [cited 2014 Feb 27];15(1):48. Available from: http://www.pubmedcentral. nih.gov/articlerender.fcgi? artid=3942305\&tool=pmcentrez\&r endertype $=$ abstract

7. Wang S-Y, Oslon-Kellogg B, Shamliyan TA, Choi J-Y, Ramakrishnan R, Kane RL. Physical Therapy Interventions for Knee Pain Secondary to Osteoarthritis A Systematic Review. Ann Intern Med 2012; 157(9):632-44.

8. Kase K, Wallis J, Kase T. Clinical therapeutic applications of Kinesio taping method. 2nd ed. Tokyo, Japan: Ken Ikai co. Ltd.; 2003.

9. Campolo M, Babu J, Dmochowska K, Scariah S, Verughese J. A comparison of two taping techniques (Kinesio and Mcconell) and their effect on anterior knee pain during functional activities. Int J Sport Phys Ther 2013;8(2):105-10.

10. Bialoszewski D, Wozniak W, Zarek S. Clinical efficacy of Kinesiology Taping in Reducing Edema of the Lower Limbs in Patients Treated with the Ilizarov Method - Preliminary Report. Ortop Traumatol Rehabil 2009;11(6):46-54.

11. Poaloni M, Bernetti A, Fratocchi G, Mangone M, Parrinello L, Cooper M del P. et al. Kinesio Taping applied to lumbar muscles influences clinical and electroyographic characteristics in chronic low back pain patients. Eur J Phys Rehabil Med 2011;47(2):237-44.

12. Fratocchi G, Di Mattia F, Rossi R, Mangone M, Santilli V, Paoloni M. Influence of Kinesio Taping applied over biceps brachii on isokinetic elbow peak torque. A placebo controlled study in a population of young healthy subjects. J Sci Med Sport [Internet]. 2013 May [cited 2014 Mar 4];16(3):245-9. Available from: http://www.sciencedirect.com/science/article/ pii/S1440244012001211

13. Mostafavifar M, Wertz J, Borchers J. A systematic review of the effectiveness of kinesio taping for musculoskeletal injury. Phys Sportsmed [Internet]. 2012 Nov [cited 2014 Feb 23]; 40(4):33-40. Available from: http://www.ncbi.nlm.nih.gov/ pubmed/23306413

14. Drouin JL, McAlpine CT, Primak K a, Kissel J. The effects of kinesiotape on athletic-based performance outcomes in healthy, active individuals: a literature synthesis. J Can Chiropr Assoc [Internet]. 2013 Dec; 57(4):356-65. Available from: http:// www.pubmedcentral.nih.gov/articlerender.fcgi?artid=384547 $0 \&$ tool $=$ pmcentrez\&rendertype $=$ abstract

15. Moore R. What is the current evidence for the use of kinesio tape? A Literature review. Sport Dyn 2012; 34(October): 24-30.

16. Warden SJ, Hinman RS, Watson MA, Avin KG, Bialocerkowski AE, Crossley KM. Patellar taping and bracing for the treatment of chronic knee pain: a systematic review and meta-analysis. Arthritis Rheum [Internet]. 2008 Jan 15 [cited 2014 Jan 25]; 59(1):73-83. Available from: http:/www.ncbi.nlm.nih.gov/ pubmed/18163413

17. Quilty B, Tucker M, Campbell R, Dieppe P. Physiotherapy, including quadriceps exercises and patellar taping, for knee osteoarthritis with predominant patello-femoral joint involvement: randomized controlled trial. J Rheumatol [Internet]. 2003 Jun [cited 2014 Mar 15];30(6):1311-7. Available from: http://www.ncbi.nlm.nih.gov/pubmed/12784408

18. Hinman RS, Lentzos J, Vicenzino B, Crossley KM. Patellofemoral osteoarthritis is common in middle-aged people with chronic patellofemoral pain. Arthritis Care Res (Hoboken) [Internet]. 2013 Dec 24 [cited 2014 Mar 17]; Available from: http://www.ncbi.nlm.nih.gov/pubmed/24376057

19. Ikeuchi M, Izumi M, Aso K, Sugimura N, Tani T. Clinical characteristics of pain originating from intra-articular structures of the knee joint in patients with medial knee osteoarthritis. Springerplus [Internet]. 2013 Jan [cited 2014 Mar 17];2:628. Available from: http://www.pubmedcentral.nih.gov/articlerender.fcgi?artid=3877413\&tool=pmcentrez\&rendertype $=$ abstract

20. The Cochrane Collaboration. Cochrane Handbook for Systematic Reviews of Interventions Version 5.1.0 [updated March 2011] [Internet]. 2011. Available from: www.cochrane-handbook.org

21. Anandkumar S, Sudarshan S, Nagpal P. Efficacy of kinesio taping on isokinetic quadriceps torque in knee osteoarthritis: a double blinded randomized controlled study. Physiother Theory Pract [Internet]. 2014 Mar 11 [cited 2014 Mar 15]; Available from: http://www.ncbi.nlm.nih.gov/pubmed/24617598

22. Karlon A, Bar-Sela S. A systematic review of the effectiveness of Kinesio Taping - Fact of Fashion? Eur J Phys Rehabil Med 2013;49:1-11.

\section{KINESIO TAPING ${ }^{\circledR}$ METHOD USING FOR PATIENTS WITH KNEE OSTEOARTHRITIS}

\section{Donec, L. Nausėdaitė, A. Daukantas, A. Beigienė}

Key words: knee osteoarthritis, patellofemoral pain syndrome, kinesio taping method.

\section{Summary}

Knee osteoarthritis (knee OA) is one of the most common forms of degenerative joint disease's which causes burden of pain in ageing population and often leads to impaired mobility and working ability, lowered quality of life. By various treatment approaches (conservative or surgical ones) it is possible to achie- 
ve less rapid progression of disease, compensation or improvement of impaired biosocial functions, improvement of quality of life and postpone disability. The aim of this review was to analyse and to summarize the main findings of randomized clinical trials, where Kinesio Taping ${ }^{\mathbb{R}}$ method was applied for knee OA population in order to lessen the pain and improve knee function. A literature search (according to the protocol) (November 2014) was performed using PubMed, Cochrane, ScienceDirect, Google Scholar databases. These searches yielded a total of 370 articles, which were reviewed thoroughly to identify suitable articles. Just one article met inclusion criteria, therefore was decided to widen inclusion criteria and include also articles about the RCT, where Kinesio Taping ${ }^{\circledR}$ method was used for knee pain or patellofemoral pain syndrome (which is also common for knee OA). These searches yielded a total of 1385 articles, which were reviewed thoroughly to identify suitable articles. Finally four papers met our criteria and were included in this systematic review. One of these studies examined Kinesio Taping ${ }^{\circledR}$ effects in on knee OA, other three - on patellofemoral pain syndrome. Treatment with Kinesio Taping ${ }^{\circledR}$ significantly improved pain levels and quadriceps peak torque in patients with knee OA immediately (after $30 \mathrm{~min}$ ) after application, the long-term results were not analysed. Studies with patellofemoral pain found insufficient evidence to indicate that Kinesio Taping ${ }^{\circledR}$ decreased pain or improved muscle function more than placebo or physical therapy alone, or electro stimulation. It was found that all authors used different taping techniques, even for the same pathology. Most of studies had high risk of bias. This systematic review found insufficient evidence to draw final conclusions towards support for using Kinesio Taping ${ }^{\circledR}$ for knee OA treatment. Further high-quality studies are needed.

Correspondence to: lina.nausedaite@gmail.com

Gauta 2015-03-09 